\title{
Overexpression, solubilization and refolding of a genetically engineered derivative of the penicillin- binding protein 3 of Escherichia coli K12
}

J. Bartholomé-De Belder, ${ }^{1}$ M. Nguyen-Distèche, ${ }^{1}$ N. Houba-Herin, ${ }^{1 *}$ J. M. Ghuysen, ${ }^{1 \S}$ I. N. Maruyama, ${ }^{2 \dagger}$ H. Hara, ${ }^{2}$ Y. Hirota, ${ }^{2 \ddagger}$ and M. Inouye ${ }^{3}$

${ }^{1}$ Service de Microbiologie, Université de Liège, Instit de Chimie, B6, B-4000 Sart Tilman (Liège 1), Belgium.

${ }^{2}$ Microbial Genetics, National Institute of Genetics, Yata-1, 111 Mishima, Shizuoka-ken, Japan.

${ }^{3}$ Department of Biochemistry, Robert Wood Johnson Medical School, University of Medicine and Dentistry of New Jersey, 675 Hoes Lane, Piscataway, New Jersey 08854-5635, USA.

\section{Summary}

Replacement of the amino-terminal 40-amino-acid region of the 588-amino-acid precursor of the membrane-bound penicillin-binding protein 3 (PBP3) by the decapeptide MKGKEFQAWI was carried out by altering the amino-coding end of the ftsl gene. Insertion of the modified gene into a runaway-replication plasmid under the control of a fused Ipp promoter and lac promoter/operator, resulted in the overexpression by Escherichia coli of the modified PBP3 (designated PBP3**) in the cytoplasm. About $80 \%$ of the accumulated PBP3 ${ }^{* *}$ underwent sequestration in the form of insoluble protein granules that were isolated by cell breakage or cell lysis. After selective removal of contaminants by an EDTA-lysozyme/DNase (deoxyribonuclease)/Nonidet extraction, treatment of the granules with guanidinium chloride followed by dialysis against buffer containing $0.5 \mathrm{M} \mathrm{NaCl}$ yielded a refolded, water-soluble PBP3**, which, upon chromatography on Superose 12, exhibited the expected 60000 molecular mass. The refolded $\mathrm{PBP}^{* *}$ bound benzylpenicillin in a 1 to 1 molar ratio, was highly sensitive to aztreonam and showed the same degree of thermostability, in terms of penicillin-binding capacity, as the parent, membrane-bound PBP3, suggesting that protein refolding occurred with formation of the correct intramolecular interactions. Two to

Received 18 March, 1988. *Present address: Max-Planck Institut für Züchtungsforschung, Köln Vogelsang Egelopfad, D-5000 Köln 30, FRG. †Present address: Molecular Genetics Unit, Medical Research Council, Cambridge CB2 2QH, UK. †Deceased (23 December, 1986). §For correspondence. three $\mathrm{mg}$ of refolded PBP3** can be obtained from 1 litre of culture of the overproducing strain.

\section{Introduction}

The term 'active-site serine, penicillin-interactive protein or protein domain' applies to a whole set of bacterial enzymes: the $\beta$-lactamases of class $A, C$ and $D$, the low- $M_{r}$ DD-peptidases/penicillin-binding proteins (PBPs), and the DD-peptidase/penicillin-binding domains of the high- $\mathrm{M}_{\tau}$ PBPs (Joris et al., 1988). A common feature of these enzymes is reaction with penicillin and other $\beta$-lactam antibiotics in a 1 to 1 molar ratio via formation of a serine ester-linked acyl (penicilloyl, cephalosporoyl) enzyme. Gene sequencing has yielded the primary structure of about 20 of these enzymes (see Joris et al., 1988) and $\mathrm{X}$-ray crystallography has revealed details of the threedimensional structure and active-site environment of several $\beta$-lactamases of class A (Kelly et al., 1986; Samraoui et al., 1986; Herzberg and Moult, 1987; Dideberg et al., 1987) and the naturally occurring, water-soluble, low-M, DD-peptidase/PBP of Streptomyces R61 (Kelly et al., 1986). On the basis of these structural data, it has been proposed that, in all likelihood, all the penicillin-interactive proteins or domains form a 'superfamily' of evolutionarily related enzymes (Joris et al., 1988). Although they have diverged greatly in terms of primary structure, and acquired varying specificities and functionalities, they would have conserved substantial similarities in their polypeptide 'scaffolding'.

In spite of these advances, determination of the threedimensional structure of the physiologically-important, high- $\mathrm{M}_{\mathrm{r}}$ PBPs $1 \mathrm{~A}, 1 \mathrm{~B}, 2$ and 3 of $E$. coli remains an important aim of the research in this field. As the results of biochemical and recombinant DNA experiments suggest, these high- $\mathrm{M}_{t}$ PBPs contain both an amino-terminal domain that catalyses a penicillin-insensitive peptidoglycan-transglycosylase reaction and a carboxy-terminal penicillin-binding domain that catalyses a penicillin-sensitive peptidoglycan transpeptidase reaction. With the exception of the aforementioned Streptomyces R61 DDpeptidase/PBP, the PBPs are membrane-bound. As a corollary, their crystallization must be achieved in the presence of detergent, an approach which so far has not yielded crystals suitable for X-ray diffraction analysis 
(Ishino et al., 1988; Ferreira et al., 1988). Alternatively, catalytically active, water-soluble derivatives can be prepared. This strategy makes use of the fact that the PBPs are essentially periplasmic proteins anchored within the membrane via their carboxy-termini (the low-M, PBPs) or their amino-termini (the high-M, PBPs). Genetically engineered, water-soluble derivatives of the E. coli PBPS 1B (Spratt et al., 1988), 2 (Adachi et al., 1988), 3 (Spratt et al., 1988) and 5 (Ferreira et al., 1988) have been obtained. The water-soluble PBP5 has yielded crystals suitable for crystallography studies (Ferreira et al., 1988).

The strategy used by Spratt et al. (1988) to obtain a water-soluble derivative of the $E$. coli PBP3 was to construct a plasmid that encoded a hybrid protein in which residues 53-588 of the PBP3 precursor were fused to the signal peptide and the first ten residues of the mature PBP5. Translocation and processing resulted in the expression of a modified PBP3 in the periplasm of $E$. coli, but the yield was low. Given that (as observed with PBP1B) the occurrence of large concentrations of PBPS in the periplasm may be lethal for E. coli (Spratt et al., 1988), experiments were undertaken with the objective of overproducing in the cytoplasm a modified PBP3 (designated $\mathrm{PBP}^{* *}$ ) that lacked the signal peptide of the precursor. As observed with many proteins synthesized intracellularly in high levels in E. coli (Marston, 1986), the overexpressed PBP3 ${ }^{* *}$ partitioned into a soluble form but predominantly underwent sequestration into cytoplasmic granules. Guanidinium chloride $(\mathrm{GuCl})$ treatment of these bodies followed by dialysis against buffer containing $0.5 \mathrm{M}$ $\mathrm{NaCl}$ yielded a 'refolded', water-soluble PBP3** which was indistinguishable from the cytoplasmic 'native' watersoluble PBP3**.

\section{Results}

\section{Intracellular synthesis of PBP3**}

A low-copy-number plasmid (pDML210; derived from pBR322) and a high-copy-number plasmid (pDML211; derived from the kanamycin-resistant, runaway-replication plasmid plM-IIA 3 ) were constructed as described in Experimental procedures and in Figs 1 and 2. These plasmids possessed a $\mathrm{ftsl}^{* *}$ gene that coded for a modified $\mathrm{PBP}^{* *}$, in which the amino-terminal 40-aminoacid region of the PBP3 precursor was replaced by the decapeptide MKGKEFQAWI. In both plasmids, the $\mathrm{fts} \mathrm{I}^{* *}$ gene was under the control of a fused lipoprotein (Ipp) promoter and lactose (lac) promoter/operator system. $E$. coli K12 derivatives were used as recipients. Bacterial growth was carried out with vigorous shaking in LuriaBertani medium supplemented with thiamine $\left(20 \mu \mathrm{g} \mathrm{ml}^{-1}\right)$ (Maniatis et al., 1982).

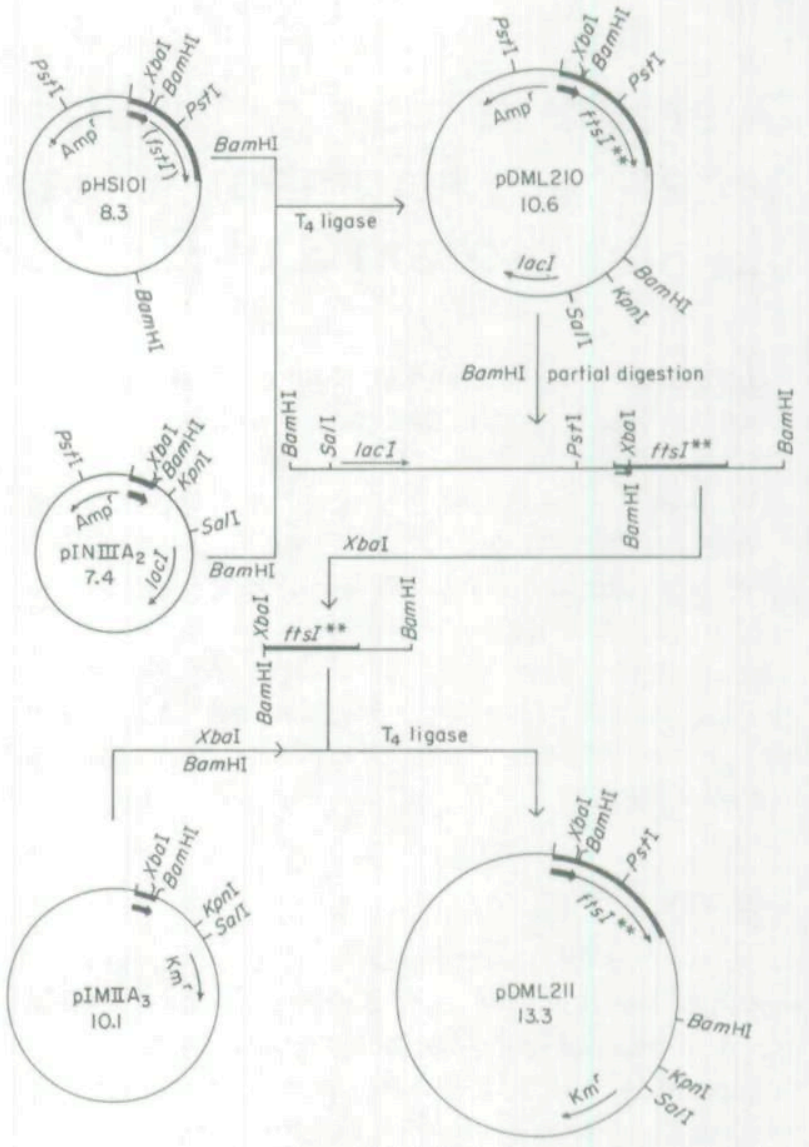

Fig. 1. Construction of plasmids pDML210 and pDML211. Heavy arrow: fused Ipp promoter, lac promoter/operator (see Fig. 2). Partial digestion of pDML210 with BamHI yielded two linearized plasmids: only one of them is represented.

The low-copy-number plasmid pDML210 (20 copies per cell) was introduced into $\mathrm{F}^{\prime} \mathrm{Iacl}^{q} \mathrm{E}$. coli JM105. The resulting strain, JDB2, was grown at $37^{\circ} \mathrm{C}$ in the presence of ampicillin $\left(50 \mu \mathrm{g} \mathrm{ml}^{-1}\right)$ until the culture reached an optimal density of 0.6 at $660 \mathrm{~nm}$. Then $2 \mathrm{mM}$ isopropyl$\beta$-D-thiogalactopyranoside (IPTG) was added and the culture incubated for a further $3 \mathrm{~h}$. Strain JDB2 accumulated small amounts of cytoplasmic granules and did not exhibit morphological abnormalities.

The high-copy-number plasmid pDML211 was introduced into $\mathrm{F}^{\prime} \mathrm{Iacl}^{q} \mathrm{E}$. coli JM105, giving rise to strain JDB4 and into $\left(\mathrm{F}^{\prime} \text { lacl }{ }^{9}\right)^{-}$and lon ${ }^{-}$E. coli GC4670, giving rise to strain JDB5. Both strains were grown at $30^{\circ} \mathrm{C}$ in the presence of kanamycin $\left(25 \mu \mathrm{g} \mathrm{ml}^{-1}\right)$ until the cultures reached an optical density of 0.1 , at which time the temperature was shifted to $37^{\circ} \mathrm{C}$. After $2 \mathrm{~h}, 2$ mM IPTG was added and the incubation of the cultures was continued for a further $3 \mathrm{~h}$. With both strains, the temperature shift led to amplification of the plasmid copy number to about 2000 per cell. In parallel to this, the cells became abnormally 


\begin{tabular}{|c|c|c|c|c|c|}
\hline Plasmid & Xoal & $\begin{array}{c}\text { Ipp signal } \\
\text { peptide }\end{array}$ & EcoRI HindIII BamHI & $\frac{\text { truncated } \mathrm{PBP}_{3} \text {-encoding }}{(\mathrm{ftsI})}$ & BamHI \\
\hline pHS101 & ATC TAG AGG GTA TTA ATA & $\begin{array}{l}\text { ATG AAA }(\mathrm{Nt})_{7-57} \mathrm{GGG} \\
\text { Met Lys (Xaa) }{ }_{3-19} \mathrm{Gl} \mathrm{y}\end{array}$ & Lys GI G PA Phe GI n Ala Trp Ile & $\begin{array}{l}\mathrm{CGG}_{123}(\mathrm{Nt})_{126-1761} \mathrm{TGC}_{1764} \mathrm{TAA} \\
\operatorname{Arg}_{41}(\mathrm{Xaa})_{42-587} \mathrm{Ser}_{588} / /\end{array}$ & \\
\hline$\underset{\text { pINIII A }}{\overrightarrow{D a n a n}}$ & ATC TAG AGG GTATTAATA & Met Lys AAA & $\begin{array}{l}\text { A AGGAATTCCAAGCTTGG ATC } \\
\text { Lys Glu Phe GIn Ala Trp Ile }\end{array}$ & & ---- \\
\hline 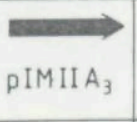 & ATCTAG AGG GTA TTA ATA & $\begin{array}{l}\text { ATG AAA } \\
\text { Met Lys }\end{array}$ & 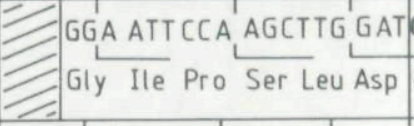 & $\begin{array}{l}\text { CCG } \\
\text { Pro }\end{array}$ & \\
\hline $\begin{array}{l}\text { PDML } 210 \\
\text { pDML211 }\end{array}$ & ATC TAG AGGGTATTA ATA & Met Lys GAA GAG & $\begin{array}{l}\text { AAG GAA TTC CAAGCT TGGATC } \\
\text { Lys Glu Phe GIn Ala TrP Ile } \\
\text { ftsI }^{* *} \text { encoding PBP }\end{array}$ & $\begin{array}{l}\mathrm{CGG}_{123}(\mathrm{Nt})_{124-\pi 761} \mathrm{TGC}_{1764} \mathrm{TAA} \\
\operatorname{Arg}_{41}(\mathrm{Xaa})_{42-587} \mathrm{Ser}_{588} / /\end{array}$ & \\
\hline
\end{tabular}

$\Rightarrow$ : fused Ipp promoter, lac promoter/operator; rbs : ribosome binding site : $\mathrm{Nt}$ : nucleotide: $\mathrm{X}$ aa : amino acid: deletions.

Fig. 2. The Xbal-BamHI DNA sequences in plasmids pHS101, pIN-IIIA $A_{2}$, pIM-IIA 3 , pDML210 and pDML211, with the translated polypeptide segments.

elongated with multiple refractile cytoplasmic bodies (protein granules) that were already visible $2 \mathrm{~h}$ after the temperature shift.

\section{Partitioning of the intracellularily synthesized PBP3**}

By definition, PBP3**, like the parent PBP3, is a $60000-M_{r}$ protein that has the ability to bind benzylpenicillin in a 1 to 1 molar ratio. Consequently, PBP3** was quantitatively estimated by submitting to gel electrophoresis in the presence of sodium dodecylsulphate (SDS), samples previously derivatized by $\left[{ }^{35} \mathrm{~S}\right]$-benzylpenicillin under saturating conditions, and by performing microdensity measurements of the Coomassie-stained and radioactive $60000-M_{r}$ protein band. In this procedure, the 349-aminoacid DD-peptidase/PBP of Streptomyces R61 (Duez et al., 1987) and its [ $\left.{ }^{35} \mathrm{~S}\right]$-benzylpenicilloyl derivative were used as references. Another feature of $\mathrm{PBP}^{* *}$ which was observed in the course of these studies, was its requirement for a high salt concentration to remain water soluble. For this purpose, a $10 \mathrm{mM}$ Tris-borate $\mathrm{pH} 8$ buffer containing $0.5 \mathrm{M} \mathrm{NaCl}, 10 \%(\mathrm{w} / \mathrm{v})$ glycerol and $0.2 \mathrm{mM}$ dithiothreitol was used: it was called buffer D. All the operations described below were carried out at $4^{\circ} \mathrm{C}$ unless otherwise stated.

Cells collected from 1 litre of cultures of strains JDB2, JDB4 and JDB5, and stored frozen at $-20^{\circ} \mathrm{C}$, were suspended in $20 \mathrm{ml}$ buffer D supplemented with $0.1 \mathrm{mM}$ phenylmethylsulphonyl fluoride (PMSF) and $0.5 \mathrm{mM}$ ethylene diamine tetraacetate (EDTA). They were disrupted by sonication (two successive treatments at $0^{\circ} \mathrm{C}$ for 1 min each, using an MSE150 watt ultrasonic disintegrator MK2 (Crawley, Sussex, UK). Suspensions of the disrupted cells were submitted to two successive centrifugations at $3000 \times \mathrm{g}$ for $5 \mathrm{~min}$ and $100000 \times \mathrm{g}$ for $4 \mathrm{~h}$, respectively. The supernatants, after a 3 -fold concentration by ultrafiltration, contained the native, water-soluble $\mathrm{PBP}^{* *}$. In turn, the pellets obtained by centrifugation at $3000 \times \mathrm{g}$ were washed with buffer D (by centrifugation at $3000 \times \mathrm{g}$ for $10 \mathrm{~min}$ ), yielding the protein granules.

Table 1 gives the yield in nmoles of $\mathrm{PBP}^{* *}$, as defined above, that were obtained from 1 litre of cultures in the form of native, water-soluble protein and protein granules. Strain JDB5 was lon ${ }^{-}$, i.e. it lacked protease L, which has an important role in the degradation of abnormal proteins (Marston, 1986). It was the best PBP3** producer and accumulated protein granules to levels ranging to $9 \%$ of total cell protein. Exposure to IPTG had little or no effect as the lac repressor was titrated out.

Properties of the native, water-soluble PBP3 ${ }^{* *}$ and refolded water-soluble $P B P 3^{* *}$ from overproducing $\mathrm{E}$. coli JDB5: comparison with the membrane-bound PBP3 of the parent strain GC4670

The native $\mathrm{PBP}^{* *}$ fraction contained all the intracellular soluble proteins and thus had a very low specific activity. It was not further studied except that upon chromatography on Superose 12 in buffer D, the PBP3 ${ }^{* *}$ eluted just after the $68000-M_{r}$ serum albumin, i.e. it behaved as a true water-soluble protein (Fig. 3, lanes 2, 3). As shown by gel electrophoresis, the $60000-\mathrm{M}_{\mathrm{r}} \mathrm{PBP}^{* * *}$ occurred as a 
Table 1. Amounts of $\mathrm{PBP}^{* *}$ synthesized by the recombinant $E$. coli strains grown in the absence and the presence of $2 \mathrm{mM} \mathrm{IPTG}$, and occurring in the form of native, water-soluble protein and protein granules. Results are given in nmoles of PBP3** produced per litre of culture, i.e. in nmoles of $60000-\mathrm{M}_{\mathrm{r}}$ protein that binds $\left[{ }^{35} \mathrm{~S}\right]$-benzylpenicillin in a 1 to 1 molar ratio. For growth conditions, see text.

\begin{tabular}{|c|c|c|c|c|}
\hline \multirow[b]{2}{*}{ Strain } & \multirow[b]{2}{*}{$\begin{array}{l}\text { Harboured } \\
\text { plasmid }\end{array}$} & \multirow[b]{2}{*}{ PBP3** forms } & \multicolumn{2}{|c|}{$\begin{array}{l}\text { PBP3 }{ }^{* *} \text { produced } \\
\text { (nmoles } \mathrm{I}^{-1} \text { culture) }\end{array}$} \\
\hline & & & $\begin{array}{l}\text { IPTG } \\
\text { absent }\end{array}$ & $\begin{array}{l}\text { IPTG } \\
\text { present }\end{array}$ \\
\hline $\begin{array}{l}\text { JDB2 } \\
\left(F^{\prime} l \mathrm{acl}^{q}\right)\end{array}$ & pDML210 & $\begin{array}{l}\text { Native } \\
\text { Granules }\end{array}$ & 2 & 4 \\
\hline JDB4 & pDML211 & Native & 4 & 6 \\
\hline $\begin{array}{l}\left(\mathrm{F}^{\prime} \mathrm{lacl}^{q}\right) \\
\text { JDB5 } \\
\left(\mathrm{F}^{\prime} \text { lacl }\right.\end{array}$ & pDML211 & $\begin{array}{l}\text { Granules } \\
\text { Native } \\
\text { Granules }\end{array}$ & $\begin{array}{c}6 \\
9 \\
40-50\end{array}$ & $\begin{array}{l}30 \\
9 \\
40-50\end{array}$ \\
\hline
\end{tabular}

For the purposes of comparison, the amounts of membrane-bound PBP3 in strain GC4670 grown under the same conditions as its derivative, JDB5, were about 0.1 nmole $\mathrm{I}^{-1}$ of culture. This value translates into about 30 copies of PBP3 per cell. A value of 50 copies was estimated by Spratt (1977).

doublet (Fig. 3, lane 3). The two protein bands reacted with the anti-membrane-bound PBP3 antibodies.

The protein granules prepared by cell breakage and centrifugation (Fig. 3, lane 4) had a specific activity of 0.15 nmoles PBP3** per mg protein (estimated purity: 1\%). Subsequently, protein granules were prepared, contaminants were selectively removed and the sequestered PBP3 was solubilized as described in Experimental procedures and illustrated in Fig. 3, lanes 4-6. Lysis of the JDB5 cells by the EDTA/lysozyme/DNase/Nonidet treatment yielded protein granules with a specific activity of 0.6 nmoles PBP3** per mg protein (estimated purity: $4 \%$ ). Gel electrophoretic analysis of these granules showed that the $60000-\mathrm{M}_{\mathrm{r}}$ protein band contained only 0.1 equivalent $\left[{ }^{35}\right.$ S]-benzylpenicilloyl moiety. Hence, $90 \%$ of this material consisted of a protein (or proteins) having a molecular mass identical to that of PBP3** but lacking penicillin-binding capacity. Treatment of the protein granules with guanidinium chloride $(1.5 \mathrm{M}, 3 \mathrm{M}$ and $6 \mathrm{M}$ concentrations gave similar results) and protein refolding by dialysis (yields: $20 \%$ of total proteins; $75 \%$ of $\mathrm{PBP}^{* *}$ ) generated a water-soluble preparation with a specific activity of 2.5 nmoles PBP3 ${ }^{* *}$ per mg protein. Though the degree of purity was still low (15\%), the refolded PBP3** was the only PBP present, it bound benzylpenicillin in a 1 to 1 molar ratio, and, upon chromatography on Superose 12 in buffer D, it eluted just after the $68000-M_{r}$ serum albumin, as observed with the native, water-soluble PBP3**. The yield in refolded PBP3** was $30-35$ nmoles $1^{-1}$ of culture of JDB5.

The native and refolded water-soluble PBPs3 ${ }^{* *}$ and the membrane-bound PBP3 exhibited exactly the same thermostability in buffer D (Fig. 4). The two water-soluble PBPs3** were half-saturated at a $0.5-0.6 \mu \mathrm{M}$ benzylpenicillin concentration. Half-saturation of the membranebound enzyme occurred at $2.5 \mu \mathrm{M}$ benzylpenicillin but one should note that, in this case, the experiments were carried out in the presence of vast amounts of other, penicillin-competing PBPs. Finally, the two water-soluble PBPs3 ${ }^{* *}$ and the membrane-bound PBP3 were half-saturated by aztreonam at a concentration lower than $0.1 \mu \mathrm{M}$. PBP3 is known to be hypersensitive to this monocyclic $\beta$-lactam antibiotic.

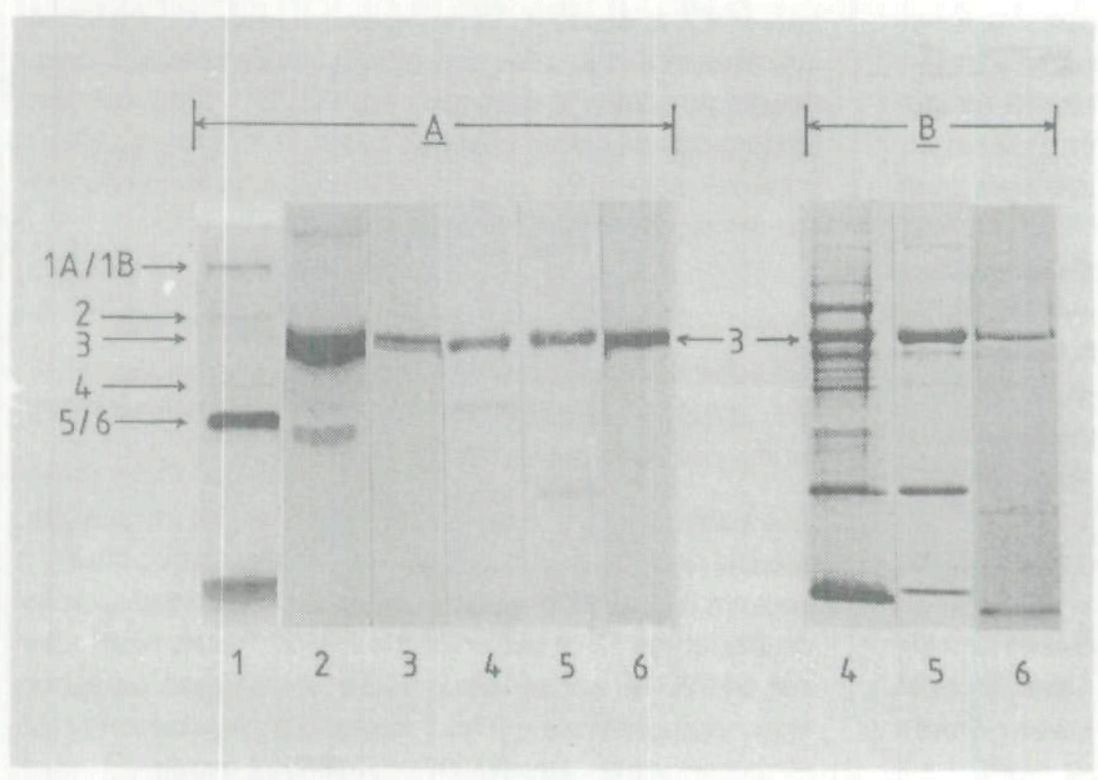

Fig. 3. Fluorograms (A) and Coomassie Brilliant Blue-stained gels (B) obtained after polyacrylamide gel electrophoresis in SDS of ${ }^{35}$ S]-benzylpenicillin-labelled enzyme samples. 1: membranes of the host $E$. coli GC4670 (110 $\mu \mathrm{g}$ protein); 2 and 3: native, water-soluble PBP3.* from $E$. coli JDB5 before (2) $(70 \mu \mathrm{g}$ protein) and after (3) $(10 \mu \mathrm{g}$ protein) chromatography on Superose 12; 4 and 5 : protein granules isolated from $E$. coli JDB5 by cell breakage and centrifugation (4) $(90 \mu \mathrm{g}$ protein) and by cell lysis and EDTA/lysozyme/DNase/Nonidet treatment (5) ( $20 \mu$ g protein); 6: refolded PBP3*" from E. coli JDB5 ( $\mathrm{A} ; 1.2 \mu \mathrm{g}$ protein) and (B; $2 \mu \mathrm{g}$ protein). 


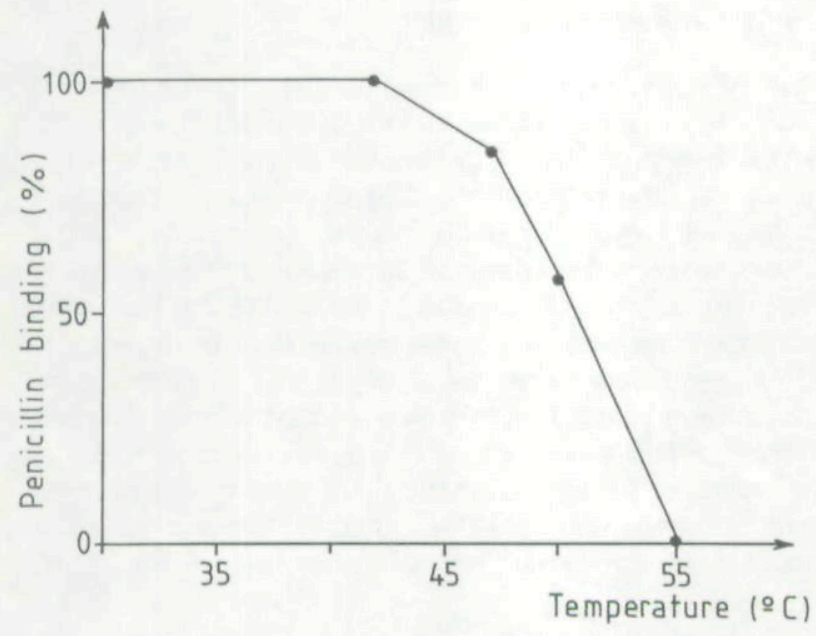

Fig. 4. Thermostability of the membrane-bound PBP3 of the host E. coli GC4670, and the native water-soluble PBP3"* and refolded watersoluble PBP3** of $E$. coli JDB5. Isolated membranes from E. coli GC4670 (144 $\mu \mathrm{g}$ protein) and the soluble PBP3s"* (1.5 picomoles), were incubated in $12 \mu \mathrm{l}$ and $8 \mu \mathrm{l}$, respectively, of buffer D for $10 \mathrm{~min}$ at the indicated temperatures. The samples were then incubated for $10 \mathrm{~min}$ at $30^{\circ} \mathrm{C}$ with $0.1 \mathrm{mM}\left[{ }^{35} \mathrm{~S}\right]$-benzylpenicillin and the amounts of $\left[{ }^{35} \mathrm{~S}\right]$-benzylpenicilloyl enzymes estimated after polyacrylamide gel electrophoresis in SDS. The three enzymes behaved identically.

\section{Discussion}

In the literature, there is an increasing number of reports showing that, when expressed intracellularly in high levels in E. coli by means of DNA recombinant techniques, 'foreign' proteins such as eukaryotic polypeptides (Marston, 1986) and both 'abnormal' and 'normal' E. coli proteins (for example the RTEM $\beta$-lactamase and EnvA protein) (Ghrayeb et al., 1984; Masui et al., 1984) accumulate as inclusion bodies, even if the authentic proteins are produced in a soluble form. This particular response of the bacterial cell caused by the accumulation of a high concentration of protein is not just a precipitation phenomenon. Solublization of the accumulated protein from these bodies requires stringent chemical conditions (the use of high concentrations of guanidinium chloride, urea, detergents, alkaline $\mathrm{pH}$, organic solvents): i.e. it can be achieved only by disrupting non-covalent hydrogen bonds, ionic and hydrophobic interactions and/or polypeptide unfolding.

In the present work, the ftsl gene that encodes the membrane-bound PBP3 of E. coli has been genetically engineered with the objective of producing, in $E$. coli, an intracellular derivative in which the amino-terminal 40 amino acids of the precursors have been replaced by the decapeptide MKGKEFQAWI. Insertion of the modified gene into a high-level expression cloning vector results in the synthesis of the modified PBP3** in the cytoplasm with a 500-fold amplification, when compared with the amounts of naturally occurring membrane-bound PBP3.

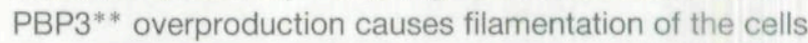
but is not a lethal event perhaps because most of the synthesized PBP3** $(80 \%)$ is sequestered in the form of protein granules. After selective elimination of contaminants from these bodies, conversion of the insoluble $\mathrm{PBP}^{* * *}$ to an unfolded random coil by guanidinium chloride treatment and refolding by dialysis against buffer containing $0.5 \mathrm{M} \mathrm{NaCl}$ yields a PBP3** that is undistinguishable from the small proportion of intracellular

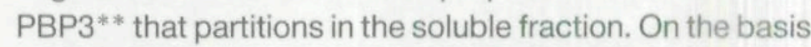
of their thermostability, their affinity to benzylpenicillin and their susceptibility to aztreonam, the penicillin-binding domain of both native and refolded water-soluble PBP3s** appear to have conserved or re-acquired a polypeptide folding which is identical, or very similar, to that of the native state. The refolded $\mathrm{PBP}^{* *}$ represents less than $10 \%$ of the protein content of the protein granules. It seems that during sequestration by aggregation, a high proportion of the synthesized PBP3** is denatured into a form that escapes recovery. In any case, these protein granules enable us to obtain, using a two-step procedure, a preparation of active PBP3** which is about $15 \%$ pure, with a yield of $2-3 \mathrm{mg}$ per litre of culture.

\section{Experimental procedures}

\section{Bacterial strains}

All strains were $E$. coli $\mathrm{K} 12$ derivatives. Strain JE7611 ( $\mathrm{F}^{-}$recA1 ftsl 730 str thi metE proC $x y l$ lacZ tonA tsx) harboured the originial plasmid pHS101 (Houba-Herin et al., 1985) (see below). Strain HB101 ( $\mathrm{F}^{-}$hsdS20 ( $\left.\mathrm{r}_{\mathrm{B}}^{-} \mathrm{m}_{\mathrm{B}}^{-}\right)$recA13 ara-14 proA2 lacY galk2 rpsL20 (Sm') xyl-5 mtl-1 supE $\left.44 \lambda^{-}\right)$(Boyer and Rouland-Dussoix, 1969), strain JM105 ( $\Delta$ (lac-pro) thi strA endA sbcB hsdR/F' traD36 proAB lacla lacZ $\triangle M 15$ ) (Messing et al., 1981), and strain GC4670 (Ion::Tn10 thr leu lach) (a gift from Dr B. Holland, University of Leicester, UK) were used as recipients of the recombinant plasmids.

\section{Plasmids (Figs 1 and 2)}

Plasmid pHS101 contained the truncated PBP3-encoding (ftS) gene (Houba-Herin et al., 1985). Plasmids pIN-IIIA ${ }_{2}$ (a derivative of pBR322) and $\mathrm{pIM}^{-1 \mathrm{~A}} \mathrm{~A}_{3}$ (a kanamycin-resistant, runawayreplication plasmid derived from $\mathrm{RI}$ ) were used as vectors (Masui et al., 1983). The general characteristics of these plasmids and a detailed map of their Xbal-BamHI sequences are shown in Fig. 1 and Fig. 2, respectively. Each plasmid possesses an ORF that is under the control of a fused Ipp promoter and lac promoter/operator system. In pHS101, the ORF codes for a chimeric protein in which the signal peptide of the murein lipoprotein is linked via heptapeptide KEFQAWI, to a truncated PBP3 that lacks the amino-terminal 40-amino-acid region of the precursor and thus lacks the cysteine residues at position 28 and 30 (so that the 
lipoprotein cleavage site Gly-Cys is modified into Gly-Lys, which is not recognized by signal peptidase 1). Downstream of this ORF, there is a second BamHI site. pIN-IIIA $A_{2}$ lacks the fts/ gene, possesses one single BamHI site and has an Xbal-BamHI insert identical to that of pHS101 except that there is a 51 nucleotide deletion in the gene encoding the signal peptide of the murein lipoprotein. The runaway-replication plasmid pIM-IIA ${ }_{3}$ also has a unique $\mathrm{BamHI}$ site, but it is in a different reading frame from the corresponding site in pIN-IIIA $A_{2}$.

\section{Construction of the low-level expression vector, pDML210 (Figs 1 and 2)}

The BamHI-(fts)-BamHI segment $(3.2 \mathrm{~kb})$ was excised from pHS101, gel-purified and inserted in the right orientation, in the BamHI site of pIN-IIIA $A_{2}$ which had been previously treated with alkaline phosphatase. The ligated mixture was used to transform E. coli HB101 and the transformants were selected on LB agar containing ampicillin $\left(50 \mu \mathrm{g} \mathrm{ml}^{-1}\right)$. Insertion of the DNA fragment in the right orientation conferred to the recombinant plasmid the distinctive property to yield, upon digestion with Pstl, two fragments of $1.8 \mathrm{~kb}$ and $8.8 \mathrm{~kb}$, respectively. Ten transformants were tested; five gave the desired response. As a result of this construction, plasmid pDML210 had under the control of the Ipp promoter and lac promoter operator system, the gene $\mathrm{ftsl}^{* *}$ coding for the desired PBP3**.

\section{Construction of the high-level expression vector,} pDML211 (Figs 1 and 2)

pDML210 was partially digested with BamHI. The linearized plasmids were isolated and digested with $X$ bal. The desired $3.2 \mathrm{~kb}$ fragment was isolated by agarose gel electrophoresis and ligated to $\mathrm{pIM}-\| \mathrm{A}_{3}$, which had been previously digested with $\mathrm{Xbal}$ and $B a m H I$. The ligated mixture was used to transform E. coli HB101 and the transformants were selected on LB agar containing kanamycin $\left(25 \mu \mathrm{g} \mathrm{ml}^{-1}\right)$. The resulting plasmid was called pDML211.

\section{Enzymes, antibodies, antibiotics and recombinant DNA techniques}

Restriction endonucleases, T4 DNA ligase and bacterial alkaline phosphatase were from Amersham International, Amersham, UK. DNasel was from Boehringer-Mannheim (FRG). Lysozyme was from Sigma Chemical Co., St Louis, MO, USA. The Streptomyces R61 DD-peptidase/PBP ( $>95 \%$ purity) was that described in Duez et al. (1987). Rabbit antisera directed against the Triton X-100purified membrane-bound PBP3 of E. coli was a gift from Dr W. Keck (University of Gröningen, The Netherlands). $\left[{ }^{35} \mathrm{~S}\right]-B e n z y l p e-$ nicillin $\left(500 \mathrm{mCi} \mathrm{mmole}^{-1}\right)$ was from New England Nuclear (Dupont de Nemours, Belgium). Ampicillin was from Beecham (Brussels, Belgium). Kanamycin was from Boehringer-Mannheim (FRG). Benzylpenicillin was from Rhône-Poulenc (Paris, France). Aztreonam was a gift from Dr Lucania (The Squibb Institute for Medical Research, Princeton, NJ, USA). $\beta$-lodopenicillanate was a gift from Dr J. Kemp (Pfizer Central Research, Sandwich, Kent, UK). All recombinant DNA techniques were based on Maniatis et al. (1982).

\section{$P B P 3^{* *}$ and protein estimation}

The PBPs were labelled with $\left.{ }^{35} \mathrm{~S}\right]$-benzylpenicillin in buffer $\mathrm{D}$ under conditions which caused complete derivatization of PBP3 ( $0.1 \mathrm{mM}$ benzylpenicillin; $10 \mathrm{~min}$ of incubation at $37^{\circ} \mathrm{C}$ ). Polyacrylamide gel electrophoresis in SDS, Coomassie Brilliant Blue staining and fluorography of the gels were carried out according to standard procedures (Laemmli and Favre, 1973; Spratt, 1977; Chamberlain, 1979). Strain JDB2 was an RTEM $\beta$-lactamase producer. In this case, the enzyme samples were treated with $5 \times$ $10^{-5} \mathrm{M} \beta$-iodopenicillanate for $20 \mathrm{~min}$ at $30^{\circ} \mathrm{C}$ (to inactivate the $\beta$-lactamase) before the PBPs were labelled with $\left[{ }^{35} \mathrm{~S}\right]$-benzylpenicillin. Proteins were estimated using Lowry's procedure with the addition of SDS (Shepherd et al., 1977). Alternatively, samples were hydrolysed with $6 \mathrm{M} \mathrm{HCl}$ at $100^{\circ} \mathrm{C}$ for $20 \mathrm{~h}$ and the amino groups were estimated after dinitrophenylation (Frère et al., 1973).

\section{Preparation of the refolded, water-soluble PBP3 ${ }^{* *}$ from} strain JDB5

The procedure was an adaptation (A. Renard, personal communication) of methods used for the isolation of polypeptides from protein granules accumulated in E. coli (Marston, 1986). Frozen cells (from 11 of culture) were suspended in $160 \mathrm{ml}$ of a lysozyme solution $\left(1 \mathrm{mg} \mathrm{ml}^{-1}\right)$ made in $50 \mathrm{mM}$ Tris- $\mathrm{HCl} \mathrm{pH} 8$ containing $0.5 \mathrm{mM}$ EDTA. The cell suspension was incubated for $15 \mathrm{~min}$ at $4{ }^{\circ} \mathrm{C}$, and then $40 \mathrm{ml}$ of $2 \mathrm{M} \mathrm{NaCl}, 2.5 \mathrm{mM} \mathrm{MgCl}_{2}, 0.5 \mathrm{mM} \mathrm{PMSF}$ $2.5 \%(\mathrm{v} / \mathrm{v})$ were added. This was Nonidet, $50 \mathrm{mM}$ Tris- $\mathrm{HCl} \mathrm{pH} 8$ incubated for $15 \mathrm{~min}$ at $4^{\circ} \mathrm{C}$. Finally, DNase $\left(10 \mu \mathrm{g} \mathrm{ml} \mathrm{m}^{-1}\right.$, final concentration) was added and the mixture was incubated for 30 $\min$ at $4^{\circ} \mathrm{C}$. The protein granules were collected by centrifugation at $10000 \times \mathrm{g}$ for $10 \mathrm{~min}$, washed three times with $20 \mathrm{mM}$ Tris- $\mathrm{HCl}-5 \mathrm{mM}$ EDTA pH 8, and suspended in buffer $\mathrm{D}$ at a final concentration of $10 \mathrm{mg}$ protein $\mathrm{ml}^{-1}$. The suspension was sonicated using the MSE 150 watt disintegrator MK2 (two successive treatments at $0^{\circ} \mathrm{C}$ for $15 \mathrm{~s}$ each), diluted 10 times with $1.65 \mathrm{M}$ guanidine chloride previously dissolved in buffer $\mathrm{D}$ without $\mathrm{NaCl}$, incubated for $30 \mathrm{~min}$ at $0^{\circ} \mathrm{C}$ and centrifuged at $30000 \times \mathrm{g}$ for 45 $\mathrm{min}$. The supernatant, dialysed against buffer $\mathrm{D}$ and centrifuged at $30000 \times \mathrm{g}$ for $45 \mathrm{~min}$, contained the refolded PBP $3^{* *}$.

\section{Chromatography on Superose 12}

Chromatography of the water-soluble PBPs3** was performed in buffer D using the FPLC Pharmacia system. Detection of the eluted PBP3 ${ }^{* *}$ was carried out by $\left[{ }^{35} \mathrm{~S}\right]$-benzylpenicillin binding and by immunoblotting using anti-membrane-bound PBP3 antibodies as reagent (Bio-Rad Immun Blot alkaline phosphatase Assay system).

\section{Plasma membrane}

Plasma membranes were prepared from E. coli GC4670 and the membrane-bound PBP3 (after labelling with ${ }^{35} \mathrm{~S}$ ]-benzylpenicillin) was estimated as described above. 


\section{Acknowledgements}

This work was supported in part by the Fonds de la Recherche Scientifique Médicale (contract no. 3.4507.83), an Action concertée with the Belgian Government (convention 86/91-90), a convention with the Région wallonne (C2/C16/Conv.246/20428), the Fonds de Recherche de la Faculté de Médecine ULg and a contract with the EEC (BAP-0197-B).

\section{References}

Adachi, H., Ohta, T., and Matsuzawa, H. (1988) A water-soluble form of penicillin-binding protein 2 of Escherichia coli constructed by site-directed mutagenesis. FEBS Lett 226: 150154.

Boyer, H.W., and Roulland Dussoix, D. (1969) A complementation analysis of the restriction and modification of DNA in Escherichia coli. J Mol Biol 41: 459-472.

Chamberlain, J.P. (1979) Fluorographic detection of radioactivity in polyacrylamide gels with the water-soluble fluor, sodium salicylate. Analyt Biochem 98: 132-135

Dideberg, O., Charlier, P., Wéry, J.P., Dehottay, P., Dusart, J., Erpicum, T., Frère, J.M., and Ghuysen, J.M. (1987) The crystal structure of the $\beta$-lactamase of Streptomyces albus $\mathrm{G}$ at $0.3 \mathrm{~nm}$ resolution. Biochem J 245: 911-913.

Duez, C., Piron-Fraipont, C., Joris, B., Dusart, J., Urdea, M.S., Martial, J.A., Frère, J.M., and Ghuysen, J.M. (1987) Primary structure of the Streptomyces R61 extracellular DD-peptidase cloning into Streptomyces lividans and nucleotide sequence of the gene. Eur J Biochem 162: 509-518.

Ferreira, L.C.S., Schwarz, U., Keck, W., Charlier, P., Dideberg, O., and Ghuysen, J.M. (1988) Properties and crystallization of a genetically engineered, water-soluble derivative of penicillinbinding protein 5 of Escherichia coli. Eur $J$ Biochem 171: 11-16.

Frère, J.M., Ghuysen, J.M., Perkins, H.R., and Nieto, M. (1973) Molecular weight and amino acid composition of the exocellular DD-carboxypeptidase-transpeptidase of Streptomyces R61. Biochem J 135: 463-468.

Ghrayeb, G., Kimura, H., Takahara, M., Hsiung, H., Masui, Y., and Inouye, M. (1984) Secretion cloning vectors in Escherichia coli. EMBO J 3: 2437-2442.

Herzberg, O., and Moult, J. (1987) Bacterial resistance of $\beta$-lactam antibiotics: crystal structure of $\beta$-lactamase from Staphylococcus aureus $\mathrm{PCl}$ at $2.5 \AA$ resolution. Science 236: 694-701.

Houba-Herin, N., Hara, H., Inouye, M., and Hirota, Y. (1985) Binding of penicillin to thiol penicillin-binding protein 3 of Escherichia coli: identification of its active site. Mol Gen Genet 201: 499-504.
Ishino, F., Wachi, M., Ueda, K.H., Ito, Y., Nicholas, R., Strominger, J.L., Senda, T., Ishikawa, K., Mitsui, Y., and Matsuhashi, M. (1988) Crystallization and preliminary crystallographic studies of the high molecular weight penicillin-binding protein, 1Bdelta, of Escherichia coli. In Antibiotic Inhibition of Bacterial Cell Surface Assembly and Function. Actor, P., Daneo-Moore, L., Higgins, M.L., Salton, M.R.J., and Shockman, G.D. (eds). Washington, D.C.: American Society for Microbiology, pp. 285-291.

Joris, B., Ghuysen, J.M., Dive, G., Renard, A., Dideberg, O., Charlier, P., Frère, J.M., Kelly, J.A., Boyington, J.C., Moews, P.C., and Knox, J.R. (1988) The active-site serine penicillinrecognizing enzymes as members of the Streptomyces R61 DD-peptidase family. Biochem J 250: 313-324.

Kelly, J.A., Dideberg, O., Charlier, P., Wéry, J.P., Libert, M., Moews, P.P., Knox, J.R., Duez, C., Fraipont, C., Joris, B., Dusart, J., Frère, J.M., and Ghuysen, J.M. (1986) On the origin of bacterial resistance to penicillin: comparison of a $\beta$-lactamase and a penicillin target. Science 231: 1429-1431.

Laemmli, U.K., and Favre, M. (1973) Maturation of the head of bacteriophage T4. J Mol Biol 80: 575-599.

Maniatis, T., Fritsch, E. F., and Sambrook, T. (1982) Molecular Cloning: A Laboratory Manual. Cold Spring Harbor, New York: Cold Spring Harbor Laboratory.

Marston, F.A.O. (1986) The purification of eukaryotic polypeptides synthesized in Escherichia coli. Biochem J 240: 1-12.

Masui, Y., Coleman, J., and Inouye, M. (1983) Multipurpose expression cloning vehicles in Escherichia coli. In Experimental Manipulation of Gene Expression. Inouye, M. (ed.) New York: Academic Press, pp. 15-32.

Masui, Y., Mizuno, T., and Inouye, M. (1984) Novel high-level expression cloning vehicles: $10^{4}$-fold amplification of Escherichia coli minor protein. Bio/Technology 2: 81-85.

Messing, J., Crea, R., and Seeburg, P.H. (1981) A system for shotgun DNA sequencing. Nucl Acids Res 9: 309-321.

Samraoui, B., Sutton, B.J., Todd, R.J., Artymiuk, J.J., Waley, S.G., and Phillips, D.C. (1986) Tertiary structural similarity between a class $A$-lactamase and a penicillin-sensitive D-alanyl carboxy-peptidase-transpeptidase. Nature 320: 378380.

Shepherd, S.T., Chase, H.A., and Reynolds, P.E. (1977) The separation and properties of two penicillin-binding proteins from Salmonella typhimurium. Eur J Biochem 78: 521-523.

Spratt, B.G. (1977) Properties of the penicillin-binding proteins of Escherichia coli. Eur J Biochem 72: 341-352.

Spratt, B.G., Bowler, L., Edelman, A., and Broome-Smith, J.K. (1988) Membrane topology of penicillin-binding proteins 1B and 3 of Escherichia coli and the production of water-soluble forms of high molecular weight penicillin-binding proteins. In Antibiotic Inhibition of Bacterial Cell Surface Assembly and Function. Actor, P., Daneo-Moore, L., Higgins, M.L., Salton, M.R.J., and Shockman, G.D. (eds). Washington, D.C.: American Society for Microbiology, pp. 292-300. 
This document is a scanned copy of a printed document. No warranty is given about the accuracy of the copy. Users should refer to the original published version of the material. 